\title{
ANALISIS STRATEGI CUSTOMER RELATIONSHIP MANAGEMENT DI PT. XYZ
}

\author{
Dion Christian Halim, ${ }^{1}$, Adi Wibowo ${ }^{2}$, dan Anita Nathania Purbowo ${ }^{3}$ \\ ${ }^{1,2,3}$ Program Studi Teknik Informatika, Fakultas Teknologi Industri, Universitas Kristen Petra \\ Jl. Siwalankerto 121-131, Surabaya 60236, Indonesia \\ E-mail:dionch@yahoo.com, adiw@petra.ac.id, anitaforpetra@gmail.com
}

\begin{abstract}
Abstrak: PT. XYZ merupakan sebuah perusahaan yang memprioritaskan customer lama. Namun dalam pelaksanaannya, PT. XYZ belum memiliki manajemen marketing yang menunjang loyalitas customer, terutama yang menggunakan media eletronik. Hal ini bisa terlihat saat perusahaan mengadakan kegiatan. Proses pemilihan customer yang menjadi peserta masih dilakukan secara manual. Selain itu, belum ada sistem yang menangani keluhan dari customer dan penawaran produk yang diberikan kepada customer lama pun belum tersistem secara jelas, hanya berdasarkan pengetahuan dan pengalaman sales force saja. Padahal, saat ini teknologi sudah sangat berkembang dan memungkinkan hal-hal ini untuk menjadi tersistem sehingga dapat meningkatkan loyalitas customer. Hasil yang diperoleh adalah penerapan Customer Relationship Management (CRM) khususnya yang menggunakan media elektronik (e-CRM) dalam strategi marketing untuk meningkatkan loyalitas customer maupun mendapatkan customer baru.
\end{abstract}

Kata kunci: Customer relationship management, e-CRM, strategi marketing, manajemen marketing.

\begin{abstract}
PT. XYZ is a company that prioritizes loyal customers. However, in its operation, PT. XYZ still has no marketing management that can support the customer loyalty, especially the electronic system ones. It can be seen when this company makes an event. The selection of the customers who can participate is done manually. In addition, there is still no system that handles the complaints from customers. Moreover, the product offering for loyal customer still has no clear system, only based on the knowledge and experience coming from sales force. On the other hand, the technology nowadays is already very developed, making it possible to make it systematic and result in high customer loyalty. The analysis results are CRM strategies, especially electronic-based (e-CRM) strategies to keep the customers loyalty and to attract new customers.
\end{abstract}

Keywords: CRM, cunstomer loyalty, e-CRM, marketing management.

\section{PENDAHULUAN}

PT. XYZ merupakan sebuah Perusahaan Swasta Nasional yang berdiri pada tahun 1942. Perusahaan ini bergerak di bidang industri mesin pertanian, dengan produk utama meliputi: traktor tangan, pompa air, mesin pengairan skala mikro, mesin pengolah beras, mesin pengering, rol karet gulungan padi, diesel engine, welder, generator set, dan kapal aluminium. Sekarang, setelah 71 tahun berdiri, perusahaan yang berkantor cabang di Jalan Ikan Dorang 7 Surabaya ini, memiliki 7 kantor cabang yang tersebar di seluruh Indonesia.

Seiring dengan berjalannya waktu, lahan pertanian yang tersedia semakin sempit, sedangkan permintaan bahan makanan semakin meningkat. Oleh karena itu, kebutuhan teknologi baru juga semakin meningkat. PT. XYZ berusaha menjawab tantangan tersebut. Hal ini terlihat dari visinya yaitu "Menjadi perusahaan penyedia perlatan pertanian terbesar di Asia Tenggara", dengan misi "Memasarkan peralatan pertanian dengan harga yang sewajarnya dan untuk membantu Pemerintah menciptakan pertumbuhan ekonomi yang stabil".

PT. XYZ memprioritaskan untuk menjalin hubungan yang baik dengan customer lama. Walaupun demikian, perusahaan belum pernah menerapkan sistem Customer Relationship Management (CRM) [1]. Padahal, saat ini penerapan CRM melalui media elektronik sangat berpotensi untuk dapat mempertahankan loyalitas customer lama maupun mendapatkan customer baru.

\section{ANALISIS STRATEGI MARKETING PERUSAHAAN}

\section{Analisis Kebutuhan Informasi Customer}

Untuk mengetahui seberapa besar peran internet dalam proses promosi dan komunikasi, serta kebutuhan informasi customer PT. XYZ, maka dilakukan survei terhadap 23 customer yang berada di daerah Jawa Timur, dengan hasil sebagai berikut: 
1. Sebanyak $91,3 \%$ atau 21 dari 23 responden menyatakan bahwa perusahaan mereka saat ini sudah dilengkapi dengan koneksi internet, hanya 2 responden $(8,7 \%)$ yang belum menggunakan internet. Responden yang sudah menggunakan internet, sebagian besar menggunakan provider Telkom Speedy $(42,86 \%)$ dan D-NET $(19,05 \%)$, sedangkan sisanya menggunakan provider Telkomsel, XL, dan Mitra Net. Biaya yang mereka keluarkan setiap bulannya untuk koneksi internet ini berkisar antaea Rp. 100.000,00 sampai Rp. $300.000,00$.

2. Sebagian besar customer PT. XYZ (76,19\%) belum memiliki email resmi perusahaan. Beberapa alasannya adalah karena hanya pimpinan atau karyawan tertentu yang memiliki email dan perusahaan mereka adalah home industry sehingga tidak memerlukan email.

3. Sebanyak 13 responden $(66,7 \%)$ selalu menggunakan internet untuk mencari informasi tentang produk yang mereka butuhkan. Sedangkan $33,33 \%$ sisanya hanya menggunakannya 1-2 kali seminggu atau hanya kadang-kadang saja.

4. Selama ini responden mendapatkan informasi tentang produk yang mereka butuhkan melalui Sales Force (76,19\%), Telepon (71,43\%), Email $(57,14 \%)$, Website $(42,86 \%)$, Brosur $(38,10 \%)$, dan Video $(14,29 \%)$.

5. Sebelum membeli suatu barang, responden memerlukan informasi seputar spesifikasi $(95,24 \%)$, harga $(90,48 \%)$, kelebihan/kekurangan $(71,43 \%)$, service $(61,90 \%)$, dan testimoni dari pembeli lain $(33,33 \%)$.

6. Seluruh responden menyatakan bahwa saat membeli suatu barang, mereka memerlukan informasi terkait perusahaan yang menjualnya. Alasan terbesarnya adalah untuk kejelasan identitas perusahaan dan service terhadap barang tersebut.

7. Sebanyak 15 responden $(71,43 \%)$ memerlukan proses pemesanan dan pembelian secara online. Sedangkan 28,58\% menganggap hal ini tidak diperlukan karena sudah ada Sales Force yang menangani proses ini.

8. Hampir seluruh responden $(95,24 \%)$ memerlukan proses pembayaran secara online.

9. Metode penyampaian informasi yang paling disukai oleh responden adalah melalui Sales Force (76,19\%), kemudian Website (71,43\%), Telepon $(61,90 \%)$, Email $(57,14 \%)$, Brosur $(38,10 \%)$, dan terakhir Video $(28,57 \%)$.

10. Semua responden menyatakan bahwa seluruh staff di perusahaan mereka mempunyai hak akses internet.

11. Sebanyak 11 responden $(52,38 \%)$ menyatakan bahwa di perusahaan mereka tidak ada batasan tertentu dalam mengakses internet. Sedangkan $47,62 \%$ sisanya memiliki batasan tertentu, salah satunya adalah youtube.

12. Keuntungan yang diharapkan dari para responden terhadap koneksi internet mereka adalah dapat melihat review produk yang akan mereka beli $(76,19 \%)$, info yang lengkap $(66,67 \%)$, dapat berhubungan dengan supplier atau customer $(57,14 \%)$, tersedia 24 jam sehari $(52,38 \%)$, dan membantu pengelolaan keuangan perusahaan $(19,05 \%)$.

13. Untuk responden yang belum menggunakan internet, alasannya adalah karena mahal dan kesulitan jaringan karena responden berada di desa.

\section{Analisis Strategi 7Ps Marketing}

Untuk membuat strategi CRM yang tepat, tidak cukup hanya menggunakan informasi yang diperoleh dari customer, tetapi diperlukan juga analisis strategi marketing yang telah dilakukan oleh PT. XYZ selama ini. Dan untuk itu, metode yang digunakan adalah melalui pendekatan 7Ps Marketing [2] dengan hasil sebagai berikut:

\section{Product}

a. Bagaimana proses pemilihan produk dan apa yang mendasarinya?

Pemilihan produk dilakukan berdasarkan kebutuhan (demand) yang diperoleh dari survey dan analisis. Survey yang dilakukan tergantung keadaan pasar dan trend yang ada di masyarakat. Setelah mengetahui hal ini barulah perusahaan akan memilih produk untuk dijual.

b. Bagaimana cara melakukan survey tentang trend dan kebutuhan pasar?

Survey dilakukan oleh Sales Force (SF) dalam bentuk pengumpulan informasi melalui percakapan dengan customer (tanpa menggunakan form/internet). Informasi ini kemudian dilaporkan kepada bagian marketing. Bagian marketing menggunakan laporan ini bersama dengan laporan penjualan dan stok, sebagai bahan pertimbangan untuk memilih produk.

c. Service apa saja yang diberikan kepada customer?

Service yang diberikan lebih bersifat aftersales service, seperti training dan penyediaan suku cadang. Karena barang yang dijual merupakan barang investasi, maka setelah transaksi penjualan terjadi, perusahaan harus memastikan bahwa produknya bisa beroperasi dengan baik. Lama training yang diberikan bervariasi tergantung jenis produknya, jika produknya tergolong mudah di-install atau 
dioperasikan, training biasanya dilakukan selama 2-3 hari, namun jika produknya tergolong kompleks memerlukan waktu sekitar 1-2 minggu.

\section{Promotion}

a. Bagaimana cara perusahaan berkomunikasi dengan customer?

Selama ini, perusahaan berkomunikasi melalui seminar, pameran, buletin pertanian, website, door to door campaign, serta telepon.

b. Berapakah jumlah visitor website per bulannya?

Untuk jumlah visitor saat ini belum dievaluasi karena website perusahaan masih dalam tahap pengembangan.

c. Informasi apa saja yang diperlukan Sales Force dalam memprospek customer?

Informasi yang diperlukan antara lain product knowledge, seperti spesifikasi dan produk pesaing. Sales Force harus bisa menjadi konsultan bagi permasalahan customer. Sales Force juga harus mampu melakukan studi kelayakan (visibility study) salah satunya untuk menghitung waktu balik modal customer (ROI) dan proyeksi ekonomis (added value) bagi target customer.

d. Bagaimana strategi perusahaan dalam melakukan promosi produk?

Pada dasarnya, strategi yang dilakukan berbedabeda sesuai dengan kategori produknya. Saat ini PT. XYZ mempunyai lebih dari 10.000 produk yang dibagi atas 6 divisi, yaitu: penggerak diesel satu silinder, mesin maritim/kapal, pra-panen, pasca-panen, mesin industri lain, dan rubber-roll. Rubber-roll sebenarnya merupakan spare-part dari mesin pasca-panen, namun karena memiliki volume transaksi penjualan yang besar, rubber-roll dipisah menjadi divisi sendiri.

Secara umum, perusahaan melakukan strategi STP (Segmenting-Targeting-Positioning) sebagai berikut:

- Segmenting

Segmenting merupakan proses pengelompokkan customer dan calon customer. Perusahaan melakukan pengelompokkan berdasarkan usia, jenis kelamin, adatistiadat, kompetitor, dan budget.

- Targeting

Targeting merupakan penentuan target produk yang dijual. Hal ini disesuaikan dengan faktor modal dan logistik (back-up stock) perusahaan.

- Positioning

Positioning adalah posisi perusahaan dalam pasar. Melalui survey dan market-share dapat diketahui posisi perusahaan apakah leader atau follower. Dengan mengetahui posisinya di pasar, perusahaan dapat menentukan strategi promosi seperti iklan, harga, dan credit policy untuk membuatnya menjadi market-leader, atau mempertahankan posisinya sebagai market-leader.

e. Bagaimana cara perusahaan untuk membuat strategi promosi?

Sales Force, selain melakukan promosi, juga bertugas mengumpulkan informasi dari customer seputar produk pesaing dan strategi yang mereka lakukan. Informasi ini kemudian dilaporkan kepada marketing untuk dianalisis. Bersama dengan beberapa laporan lain seperti laporan penjualan dan stok, marketing menentukan strategi promosi untuk setiap divisinya.

f. Apakah perusahaan memiliki program promo atau discount?

Ya, program promo merupakan program rutin yang sudah di-planning sebelumnya dan memiliki periode yang sudah pasti. Proses planning ini dilakukan berdasarkan pengalaman, data, dan forecasting. Sebagai contohnya, karena perusahaan ini bergerak di bidang pertanian, maka salah satu program discount diadakan berdasarkan musim. Pada musim kemarau diberikan discount untuk produk pompa air, sedangkan pada musim hujan diberikan discount untuk produk traktor.

\section{Price}

a. Apa saja metode pembayaran yang ada?

Untuk dealer atau customer yang merupakan customer tetap, perusahaan menyediakan fasilitas kredit. Sedangkan untuk customer biasa hanya dapat melakukan transaksi secara tunai dan melibatkan lembaga keuangan seperti bank dan leasing.

b. Apakah saat menentukan harga produk, perusahaan juga memperhitungkan kompetitor?

Ya, perusahaan memperhitungkan beberapa hal seperti laporan dari Sales Force tentang kompetitor, dan juga positioning perusahaan dan kompetitor dalam pasar.

4. Place

a. Di mana saja tempat pertemuan dengan customer?

Paling sering terjadi di tempat customer, kemudian di seminar dan tempat pameran.

5. People

a. Siapa saja perusahaan pesaing PT. XYZ?

Pada umumnya, PT. XYZ tidak memiliki pesaing perusahaan lokal (Indonesia) karena PT. XYZ merupakan satu-satunya perusahaan 
di Indonesia yang memproduksi mesin pertanian. Pesaing utamanya adalah PT. Kubota Indonesia dan PT. Yanmar yang merupakan perusahaan asing.

6. Process

a. Bagaimana cara perusahaan untuk mendapatkan customer baru?

Perusahaan mengumpulkan informasi seputar perusahaan yang baru akan melakukan investasi melalui Sales Force. Berdasarkan informasi tersebut, perusahaan akan memberikan target customer untuk diprospek oleh Sales Force.

b. Seberapa jauh peran IT dalam proses yang ada?

Di PT. XYZ, semuanya sistemnya sudah terintegrasi dengan komputer, seperti aplikasi Global Business System untuk membuat invoice sampai pada laporan yang dibutuhkan oleh management yang sudah digunakan sejak tahun 2005 dan aplikasi General Ledger untuk akuntansi sejak tahun 2010.

c. Apakah perusahaan melakukan penawaran produk-produk sejenis kepada customer? (data mining)

Ya, customer selalu diberikan penawaran produk-produk inovatif, namun belum tersistem, hanya berdasarkan pengalaman dan pengetahuan Sales Force.

7. Physical Evidence

a. Seberapa dalam Sales Force menguasai informasi tentang produk?

Product knowhow, yaitu informasi seputar kegunaan dan spesifikasi produk dan product knowledge, yaitu cara mengoperasikan suatu produk.

b. Seberapa dalam sales mengenal tentang internet?

Pengetahuan standar seperti pada umumnya dan nantinya akan dibekali pengetahuan tentang $e$ catalog.

\section{Analisis Perbandingan Strategi Marketing dan Tanggapan Customer}

Berdasarkan hasil kuisioner dan analisis 7Ps Marketing pada bagian sebelumnya, maka diperoleh hasil beserta usulan sebagai berikut:

1. Berdasarkan kuisioner poin 1, hampir seluruh customer PT. XYZ (91,30\%) sudah berlangganan internet dan menggunakannya untuk mencari informasi seputar produk yang dibutuhkan (poin 2). Kedua hal ini menunjukkan bahwa e-CRM memiliki potensi yang sangat besar baik untuk mempertahankan customer yang sudah ada maupun mendapatkan customer baru.
2. Berdasarkan kuisioner poin 4 , selama ini lebih dari setengah customer PT. XYZ mendapatkan informasi produk melalui email. Poin ini juga menunjukkan bahwa media email merupakan media elektronik peringkat pertama yang digunakan customer untuk mendapatkan informasi. Walaupun berdasarkan kuisioner poin 2, hanya seperempat customer yang memiliki email resmi perusahaan, tidak menutup kemungkinan bahwa customer menggunakan email pribadi untuk mendapatkan informasi. Oleh karena itu, email menjadi salah satu media eCRM yang penting yang dapat dimanfaatkan oleh perusahaan, mengingat selama ini belum ada mail-campaign atau promosi yang menggunakan media email. Dengan melakukan clustering berdasarkan transaksi pembelian, perusahaan dapat melakukan cross-selling terhadap customer yang kemudian ditawarkan melalui media email.

3. Selama ini, media komunikasi elektronik yang digunakan oleh PT. XYZ hanyalah website. oleh karena itu, observasi yang dilakukan dalam penelitian ini juga terbatas pada website. Berdasarkan kuisioner poin 5 , customer memerlukan informasi tentang spesifikasi, harga, kelebihan dan kekurangan, layanan, serta testimoni sebelum mereka membeli suatu produk. Website perusahaan saat ini, sudah menyediakan informasi tentang spesifikasi dan layanan [3]. Harga produk tidak dicantumkan di website karena PT. XYZ sudah memiliki channel distribusi sendiri yaitu melalui dealer-dealer, dan masing-masing dealer memiliki hak untuk menentukan harga atas produknya sendiri. Selain itu, harga sebuah produk bisa bervariasi sesuai dengan daya beli daerah dan dapat dijual secara paket sesuai permintaan customer. Kelebihan dan kekurangan produk tidak dicantumkan karena sudah tertulis di brosur yang dibawa oleh Sales Force saat memprospek customer. Testimoni dari customer tidak dapat dicantumkan karena produk yang ditawarkan oleh PT. XYZ merupakan barang modal sehingga yang dibeli oleh customer merupakan rahasia customer dimana orang lain tidak perlu mengetahuinya. Mengingat informasi tentang harga serta kelebihan dan kekurangan produk menjadi kebutuhan yang sangat penting bagi customer (peringkat 2 dan 3), akan lebih baik untuk ke depannya jika website perusahaan dilengkapi dengan informasi-informasi ini. Jika harga suatu produk bervariasi, maka harga yang dicantumkan di website cukup harga dasarnya saja, sedangkan untuk kebutuhan khusus yang mempengaruhi harga dapat diperoleh customer melalui media yang lain. 
4. Berdasarkan kuisioner poin 7 , sebanyak $71,43 \%$ customer memerlukan proses pemesanan dan pembelian secara online yang saat ini belum disediakan oleh PT. XYZ. Akan lebih baik jika PT. XYZ menyediakan fasilitas ini ke depannya, mengingat customer yang membutuhkannya lebih dari setengah. Hal ini juga dapat menjadi kesempatan yang baik bagi perusahaan untuk melakukan cross-selling. Perusahaan dapat menyediakan fasilitas pemesanan dan pembelian produk online dimana setelah customer menginputkan produk yang ingin dibeli, perusahaan akan menanggapinya dengan menghubungi customer tersebut via telepon. Melalui telepon ini perusahaan akan mengkonfirmasi ulang pemesanan customer dan memiliki kesempatan untuk melakukan cross-selling dengan menawarkan produk-produk lain kepada customer. Setelah seluruh pesanan dikonfirmasi, barulah pesanan ini diproses.

5. Berdasarkan kuisioner poin 8 , hampir seluruh customer memerlukan proses pembayaran secara online. Selama ini, perusahaan belum menyediakan fasilitas ini karena perusahaan juga belum menyediakan fasilitas pembelian secara online. Hal ini berhubungan dengan poin 5 di atas, dimana jika perusahaan sudah menyediakan layanan pemesanan dan pembelian barang secara online, akan lebih baik juga melengkapi fasilitas pembayaran online. Sehingga, setelah perusahaan melakukan konfirmasi pemesanan via telepon, customer akan diminta untuk mengakses website perusahaan sekali lagi untuk melakukan pembayaran. Harga yang muncul adalah akumulasi dari seluruh pemesanan customer beserta tambahan pesanan cross-sellingnya jika ada. Hal ini akan menjadi nilai tambah yang besar bagi perusahaan karena proses pembelian bagi customer menjadi lebih mudah.

6. Berdasarkan analisis 7Ps Marketing poin 2a, selama ini perusahaan sudah berkomunikasi dengan customer melalui beberapa cara yang sudah sesuai dengan keinginan customer pada kuisioner poin 9, yaitu melalui website dan telepon. Namun, mengingat saat ini customer PT. XYZ sedang dalam masa peralihan ke generasi muda yang sudah akrab dengan internet, maka komunikasi secara online yang tidak memerlukan tatap muka langsung juga dapat menjadi alternatif yang bagus. Perusahaan dapat memanfaatkan kesempatan ini untuk mengembangkan komunikasinya dengan e-CRM seperti online support, website, email, dan social media. Semakin banyaknya alternatif media komunikasi yang dapat dilakukan, akan mempermudah perusahaan dalam menjalin relasinya dengan customer yang sudah ada maupun untuk melakukan promosi untuk mencari customer baru.

7. Berdasarkan analisis 7Ps Marketing poin 4a, perusahaan paling sering berkomunikasi dengan customer di tempat customer yang berarti sebagian besar merupakan door to door campaign yang dilakukan oleh Sales Force. Berdasarkan analisis 7Ps Marketing poin 6a, cara perusahaan mendapatkan customer baru adalah menggunakan informasi yang dikumpulkan oleh Sales Force. Dari kedua poin ini dapat terlihat bahwa Sales Force merupakan ujung tombak bagi perusahaan untuk menjalin relasi dengan customer serta memperoleh customer baru. Hal ini juga menunjukkan bahwa selama ini PT. XYZ menggunakan filosofi bahwa customernya merupakan tipe lean-back [1], yaitu tipe customer yang harus didatangi langsung atau diberikan promosi secara langsung untuk menstimulasi mereka melakukan pembelian. Padahal, saat ini orang-orang mulai beralih menjadi customer dengan tipe lean-forward, dimana customer akan aktif mencari informasi mengenai produk-produk yang mereka butuhkan. Hal ini dapat menjadi kesempatan bagi PT. XYZ untuk menambah alternatif promosinya, dimana saat ini yang diperlukan adalah memberikan cara promosi one-to-some atau one-to-one untuk menstimulasi customer untuk lean-forward dan aktif mencari informasi dari media-media komunikasi yang telah disediakan perusahaan. Salah satu cara promosi yang dapat dilakukan adalah dengan mengirimkan email penawaran produk-produk tertentu untuk kelompok customer tertentu. Untuk menentukan kelompok customer dan produk yang ditwarkan dapat diperoleh dengan data mining.

\section{KESIMPULAN DAN SARAN}

Dari hasil analisis strategi marketing dan pembuatan aplikasi e-CRM PT. XYZ, dapat diambil beberapa kesimpulan antara lain:

- Sistem e-CRM memiliki potensi yang besar untuk mempertahankan customer yang ada maupun mendapatkan customer baru, mengingat hampir seluruh customer perusahaan sudah menggunakan internet dan sekarang mulai terjadi peralihan dari generasi tua ke generasi muda yang sudah akrab dengan istilah internet.

- Perusahaan dapat memanfaatkan mail-campaign untuk meningkatkan penjualannya karena sebagian besar customer selama ini banyak mendapatkan info produk melalui email. 
- Perusahaan dapat memanfaatkan teknologi dan website untuk menyediakan fasilitas pembelian dan pembayaran secara online yang kemudian juga dapat dimanfaatkan untuk cross-selling produk.

- Website perusahaan sebaiknya tetap di-maintenance secara berkala untuk memastikan informasi yang disediakan merupakan informasi terbaru serta lengkap dan dapat menjawab kebutuhan customer.

\section{DAFTAR PUSTAKA}

1. Chaffey, D. (2009). E-Business and E-Commerce Management: Strategy, Implementation and Practice $4^{\text {th }}$ ed. London: FT Prentice Hall.

2. The Chartered Institute of Marketing. 2009. Marketing and The 7Ps: A Brief Summary of Marketing and How It Work.

3. PT. XYZ. (2013). Profile. [Online]. Tersedia: www.xyz.co.id [8 November 2013]. 